\title{
Conflicting strategies towards sustainable heating at an urban junction of heat infrastructure and building standards
}

\author{
Philipp Späth and Harald Rohracher
}

\section{Linköping University Post Print}

\section{Tweet}

N.B.: When citing this work, cite the original article.

Original Publication:

Philipp Späth and Harald Rohracher, Conflicting strategies towards sustainable heating at an urban junction of heat infrastructure and building standards, 2015, Energy Policy, (78), 273280.

http://dx.doi.org/10.1016/j.enpol.2014.12.019

Copyright: Elsevier

http://www.elsevier.com/

Postprint available at: Linköping University Electronic Press

http://urn.kb.se/resolve?urn=urn:nbn:se:liu:diva-114822 


\title{
Conflicting strategies towards sustainable heating at an urban junction of heat infrastructure and building standards ${ }^{1}$
}

\author{
Philipp Späth ${ }^{\mathrm{a}}$, Harald Rohracher ${ }^{\mathrm{b}}$ \\ a Institute of Social Environmental Sciences and Geography, University of Freiburg, Tennenbacherstrasse 4, 79106 Freiburg, Germany \\ ${ }^{\mathrm{b}}$ Department of Thematic Studies - Technology and Social Change; Linköping University, Sweden
}

\begin{abstract}
Approaches to 'sustainability transitions' stress the possibility of aligning actors around a shared vision of the future, e.g. at the scale of a city. Empirical accounts reveal how difficult such coordination often is due to contradictory views involved. How can we better understand related processes of searching and negotiation? What does this mean for the organization of decision making processes regarding long-term infrastructural change?

We analyze a conflict which erupted in Freiburg, Germany when two strategies of reducing environmental impacts of space heating were to be applied in the Vauban 'model district': A) Efficient co-generation of heat and power (CHP) combined with district heating systems (DHS), and B) Reducing heat demand by low-energy designs and ambitious energy standards ('passive house standard'). In order to understand the politics of infrastructure development, we unravel 1) enabling factors and driving forces of the conflict, 2) normative content of opposing viewpoints, 3) resources tapped into for settling the disagreement, and 4) the institutional setup of such decision making about energy policy priorities in the municipality. We reflect on implications of such a perspective on how policies and how governance arrangements should ideally be shaped and take a brief outlook on further research needed.
\end{abstract}

\section{Introduction}

The great challenges of climate change and the depletion of natural resources are strongly related to the ways in which energy is provided and consumed in contemporary societies. Accordingly, energy governance is concerned with shifting the system of energy provision and consumption towards a more sustainable configuration. To which extent such a shift can be managed by intentional policy interventions, and what role local activities can play in fostering change within globally entrenched energy structures are still open questions.

Concepts of 'sustainability transitions' stress the alignment of actors around a shared vision of the future (Brown et al., 2013; Hess, 2014) as a means to coordinate change. This is believed to work also at the scale of a city, producing momentum of change in a locally defined infrastructural system (Frantzeskaki and Loorbach, 2010). At the same time, empirical accounts and conceptualizations of socio-technical change acknowledge that coordinating such processes is only partially possible, challenged by a multitude of priorities, perceptions and often contradictory views and therefore is necessarily conflict-laden. In reality, and particularly in democratic societies, the search for a shared orientation with regard

\footnotetext{
${ }^{1}$ Published in: Energy Policy 78: 273-80; doi:10.1016/j.enpol.2014.12.019
} 
to such complex systemic endeavors will necessarily remain a distributed and messy process which is in principle prone to mistakes and conflicts. How can such processes of searching, contestation and negotiation be better understood? What does this mean for the organization of decision making processes regarding long-term infrastructural change?

We set out to analyze a discussion process concerning two energy policy strategies aiming to reduce environmental and climate impacts of space heating in Freiburg, Germany. The first strategy aims at the efficient provision of heat from co-generation of heat and electricity in semi-centralized, combined heat-and-power (CHP) stations and distribution through district heating systems (DHS). The second strategy aims at a reduction of heat demand by developing highly energy efficient building designs and enforcing ambitious energy standards like the 'passive house standard' for new buildings. Both strategies are an inherent part of urban sustainability concepts. They have been rather uncontested and received support from politicians and civil society activists alike. Contentious debates around these issues only erupted in the mid 1990's, when both strategies were applied at a larger scale in a newly developed urban district of Freiburg, the Vauban environmental 'model district' of Freiburg, and led to a clashing of interests and of different strategies for future heat supply infrastructures.

In this article we develop an understanding of urban infrastructure changes and politics of urban sustainability which puts more emphasis on such arenas of concern and their capacity to mediate transformation processes. We pursue this goal by first unravelling the driving forces of this emerging conflict as well as the normative content of the opposing viewpoints. Furthermore, we ask what factors were fostering the outbreak of the conflict and what resources actors tapped into in order to settle the disagreement. We are also interested in the institutional setup of such decision making about energy policy priorities in a municipality and the way municipal actors are able to deal with (and make use of) such instances where visions and strategies of sustainable development become problematic and negotiable again.

After critically engaging with some of the conceptual foundations of transition studies in the following section, we briefly describe our methods (section 3) and devote the majority of this paper to the description (section 4) and discussion (section 5) of a process of public contestation and multi-lateral negotiations around the obligation to connect passive houses to a district heating network in the planned 'model district of Vauban' in Freiburg, Germany. In our conclusions (section 6) we reflect on possibilities of policy making in this context and map out some pathways for future research.

\section{How to understand the micro-politics of socio-technical transitions?}

Today, the energy system is often conceptualized as a complex, socio-technical system comprising of material aspects (like infrastructures), institutional aspects (like laws, standards, tariffs etc.) and further societal norms and expectations (Grin et al., 2010). A well-known heuristic for explaining stability and change in such systems is the multi-level perspective (MLP) of socio-technical transitions, which distinguishes between niches, socio-technical regime and landscape as three levels of increasing 'structuration'. This means that agency is 
located mostly in highly fluid niches, while the particularly long-lasting and more structural elements are attributed to the landscape level, and the regime is located at an intermediary level. MLP hence puts an emphasis on stability at the regime and landscape levels. According to this view, transitions in regime configurations are often initiated by nurturing and protecting experimentation in socio-technical niches although finally interlinked changes at all three levels are required. An important strategy to manage change thus is the co-ordination of dispersed action via the creation of shared visions of a desirable (sustainable) future state of such regimes. The latter assumption has been at the basis of guidelines for the governance of sustainability transitions, which have been successfully promoted among academics and policy makers alike under the name of transition management (TM).

As a complement to this widely applied approach, we want to shift our attention also to processes of contestation and less structured and harmonious search processes at the regime level, e.g. with regard to infrastructural decisions on a city level that are of high relevance for an attempted transformation of the local energy system. We propose this shifting or broadening of our attention based on multiple observations of regime dynamics particularly in pluralistically organized urban contexts (omitted: references to own works). Such a perspective conceives of transition strategies not so much as the (participatory) identification and implementation of consensual transition pathways, but rather emphasizes the emergent and contentious character of such change processes.

We want to refine our conceptual tools for studying ongoing processes of sense-making and re-framing of problems and for analyzing social arenas where problems of change are interpreted and framed differently by different actor groups and where conflicting perspectives come to the fore. The notion of "arena of development" (Jorgensen and Sorensen, 1999, Valderrama and Jorgensen, forthcoming) seems to provide a promising perspective that may well complement the traditional repertoire of the MLP which confines innovation largely to niche level developments and focuses our attention with regard to the regime level largely on consensual vision building activities:

Compared to the MLP the AoD approach downplays the consistency of rules and mechanism of the regimes level, as the introduction of regime level tensions and inconsistencies allows for studying situated actors political engagement in conflicts and sense-making dynamics through their performed interventions." (Jorgensen, 2012: 1008)

So far, most analyses of socio-technical transitions have studied the development of regimes at the level of national or global energy systems. Furthermore, they often isolated particular functions or infrastructures (e.g. the electricity system) or emphasized particular actor perspectives (in energy mostly the supply side, rarely the demand side).

This coincided with an often compartmentalized view of practitioners in policy making, separating 'policy fields' like mobility, housing, energy etc. or focusing their interventions even on sub-systems like the electricity system, a heat network etc. However, if studied in detail, and particularly from an urban perspective, these separate 'systems' are usually highly interconnected - be it technically, institutionally or organisationally. Recent empirical research indicates that cities are special sites for the reconfiguration of socio-technical 
systems due to the fact that in cities the interplay of infrastructures, their supply and the demand sides and in general of policy fields and policy objectives is particularly conspicuous, in cases also better manageable, but very often more contested than on other levels (Coutard and Rutherford, 2010; Rutherford, 2013; omitted: reference to own work). This may result from proximities between actors, their limited number and the visibility of citizens which often represent conflicting interests (Hodson and Marvin, 2010; Monstadt, 2009).

Studying transition dynamics in great detail requires an appreciation of the particular interrelatedness of various change processes in such urban contexts. It is likely that in cities diverse infrastructures, non-aligned policy objectives and in general diverging interests and perspectives of a variety of social groups intersect. Socio-technical change becomes an inconsistent and conflict ridden process which reflects specific topographic, infrastructural, institutional and cultural conditions of the locality.

Projects of urban change often create new intersections between different sociotechnical systems and bring certain conflicts and frictions to the fore. Such nexus arrangements have recently been conceptualized as 'urban junctions' (Jensen et al., 2013). Interpreting the opening of the Copenhagen harbor to bathing, Jensen and colleagues understand this development not merely as a niche in which new (and potentially more sustainable) socio-technical configurations are tested and stabilized. Such projects, they claim, often rather mediate between different infrastructure systems, different logics of demand and supply, and between social groups with particular interests etc. They hence form intersections at which different visions and perspectives of urban change are confronted with each other and are negotiated and may eventually lead to the emergence of new socio-technical configurations (e.g. through repercussions of harbor bathing on the wastewater infrastructure) which stretch far beyond limited socio-technical niches and cannot be fully understood within the multilevel change logics of e.g. the water infrastructure alone.

With the following analysis, we seek to specify and test a number of questions that need to be asked in order to understand the dynamics at play in such situations.

\section{Methods}

We set out to study a single case of contentious negotiations about energy policy strategies which negatively influenced each other as they were implemented in one and the same district development.

Our case description is based on an analysis of documents of major influence including bills that were proposed to the city council, discussion papers, press articles, campaigning materials and other documents. Secondly, the description is based on ten in-depth interviews with eight individuals who participated in or observed the conflict from a diversity of perspectives, ranging from that of a key member of the city council via that of a founder and energy political voice of Forum Vauban, the central organization involved in the conflict and those of other activists through to the more distanced views of scientists and journalists. Some interviews had been conducted as early as in 2004. Some follow-up interviews, particularly concerning the later developments, have been conducted in 2009, 2012 and 2014 and most of 
the complementing document analysis has been conducted in 2012 and 2014. A draft version of this manuscript has been commented and the factual content has been confirmed by one of the key interview partners.

\section{Case Study: Two strategies towards green heating in conflict}

\subsection{The context: A widely shared ambition to pioneer with an urban energy policy}

Freiburg is a city with about 220.000 inhabitants in South West Germany. As early as 1986, the city council decided on three priorities for a specific energy policy in the city: to transition towards a highly efficient co-generation of electricity and heat, to increase the share in renewable energy and to abandon electricity from nuclear power (Freiburg City Council, 1996a). Since then, these objectives frequently served as a reference point and have not been fundamentally contested. The energy policy ambitions and the policy measures implemented in Freiburg have contributed to the award of various prizes, from "The Environmental Capital of Germany” in 1992 to the „The Most Sustainable Large City of Germany” in 2013. Debates in the Freiburg city council - e.g. before setting unprecedentedly strict energy standards for new buildings - repeatedly reflected a widely shared pride in the pioneering role which has resulted from the city pursuing such a well- recognized local energy policy.

\subsection{The strategy to set up district heating networks for efficient co-generation}

In the late 1960's and early 1970's, several urban expansions were built in the western outskirts of Freiburg in order to accommodate for the growing population. In line with the local energy policy ambitions, but also reflecting a widespread practice at that time, these newly built districts were each equipped with a district heating network. This allowed for a productive use of heat which was locally generated in so-called 'co-generation' of heat and electrical power (or 'CHP') and resulted in much higher overall efficiency rates than a separate generation of heat and electricity. Furthermore, one such district heating network system was run in a particularly climate friendly way on basis of methane collected from a municipal landfill. Since the late 1980's, the energy utilities in Freiburg built up further CHP capacities in all larger municipal swimming facilities. In the early 1990s, the retrofitting of an old CHP plant at a chemical industry site was used to increase the capacity at this site alone to $60 \mathrm{MW}$ electrical and $200 \mathrm{MW}$ thermal in a joint venture between the industrial company and the municipal utilities (Badenova, 2014). The growing capacities in CHP were now large enough to provide for a significant share of the city-wide electricity demand in exemplary efficiency. New technological and economic developments also reduced the risks involved in fueling new CHP plants with woodchips. In this case, two of the energy policy objectives were met at the same time: to increase the share of highly efficient co-generation and to increase the share of renewable energy sources. When in the early 1990s, a new district called Rieselfeld was developed for about 11,000 inhabitants in the west of Freiburg, it was decided without much debate that the whole area would be serviced via a district heating network in 
order to continue a very successful and up-to date energy policy agenda. (Fraunhofer IAO et al., 2013: 58)

\subsection{The evolution of low energy standards and 'solar architecture' in Freiburg}

Aiming at both, increased energy efficiency and reduced fossil fuel dependency, actors in Freiburg lobbied since the late 1980s for the enforcement of particularly low energy standards for new buildings. Forming part of a broader movement in Germany and Austria (Lauridsen and Jensen, 2013) architects and energy experts promoted experiments in low energy construction and lobbied for a regulation of energy standards. In 1992 the city council enacted the so called 'Freiburg low energy building standard' which required new buildings to be designed and insulated in a way that the heating demand does not exceed $65 \mathrm{kWh}$ per $\mathrm{m}^{2}$ and year (according to a specifically defined and strict calculation method). Going even beyond this high standard, in the following years several buildings have been built in Freiburg which demonstrated a new 'passive house' or 'solar' paradigm in both residential and office building architecture: combining measures for a maximized use of direct solar radiation with good insulation and shading, they reduced annual heating demand to less than $20 \mathrm{kWh} / \mathrm{m}^{2}$ and year or even overcompensated heating demand with on-site solar energy generation. Pointing to these demonstration projects, as well as to manifold research activities in Freiburg, to the ambitiously set energy standards and to other successes, local energy experts and the mayor began to speak of Freiburg even as a 'solar city' in the mid 1990's. What remained to be demonstrated was that the concepts successfully applied at the scale of individual buildings will also work and bring about even more positive effects if applied at the scale of a whole district.

4.4 An opportunity to plan for a new district raises ambitions to set a model for sustainability - in a participatory way

After German reunification, the French military left a compound vacant that it had used since shortly after the end of world-war II. The area of roughly 42 hectare is located at the southern fringe of Freiburg, close to a small mountain covered by woods and meadows, including some protected natural habitats. At the same time, is still very close to the city center - about $3 \mathrm{~km}$ from the main station. This very suitable and perfectly located land became suddenly available after decades in which the rising demand for housing in Freiburg has not been met. It was therefore decided unanimously to develop the area into a residential district for about 5.000 people.

Shortly after this opportunity opened up, engaged citizens started to lobby for their idea to plan for a showcase or 'model district' of sustainability in this setting, referencing to the concept of sustainable development as discussed particularly since the UNCED conference of Rio in 1992. They established a new organization called 'Forum Vauban' and adopted an official role as facilitator in the participatory planning of the new district. After successfully applying for public money in several instances, they built up staff capacity and expertise on 
current debates of planning for sustainability, especially in the fields of mobility and energy planning. Due to their persistence and due to the fact, that their conceptualization of a planning process was selected for presentation as a 'best practice case' at the Habitat Conference in Istanbul in 1996, the mayor and large parts of the city administration finally also subscribed to their ambitions (Hermann et al., 1996; Rüskamp, 1996; Sperling, 1999; interview results).

The main development plans which the city council decided upon in 1997 (Freiburg City Council, 1997b) and also the sectorial plans in energy (Freiburg City Council, 1996b) and mobility (Lange, 2009; Lange et al., 2003) reflected many of the ideas that have been developed by people associated with Forum Vauban (Forum Vauban - Mobility WG, 1995; Forum Vauban, 1996). Also regarding the question how public spaces were to be designed, Forum Vauban organized and facilitated meetings in which future inhabitants voiced their opinions.

\subsection{The incommensurability of the two strategies in one place becomes visible}

The development area of Vauban was sufficiently close to an existing heat network to create an inter-connected heat network in the new district. It was therefore decided very early in the planning process to equip the whole future district with a district heating system and a new CHP station. As usual in such cases, the municipality would then require all buildings in the respective area to be connected to the heat network.

More contentious was the question of which parts of the area shall be designated to buildings of improved solar architecture and the passive house standard. The city was increasingly branded a 'solar city' at the time, and the Forum Vauban and others argued that the layout of the whole district should be optimized for solar gains by creating large façades in southern and northern exposition to be exploited by large areas of glass (southwards) and highly insulated walls (northwards). Based mostly on aesthetic and historical arguments, however, a town planner won over the city council and the jury in a design competition in favor of a layout that foresees the majority of buildings to stretch roughly from south-north, hence maximizing east and west facades. Only on about $2.5 \%$ of the sites buildings were allowed to stretch from east to west, allowing for larger south and north facades (City of Freiburg, 2011). The parties buying these sites, however, all had to contractually agree to build passive houses (with a heat demand lower than $15 \mathrm{kWh} / \mathrm{m}^{2} *$ a). 


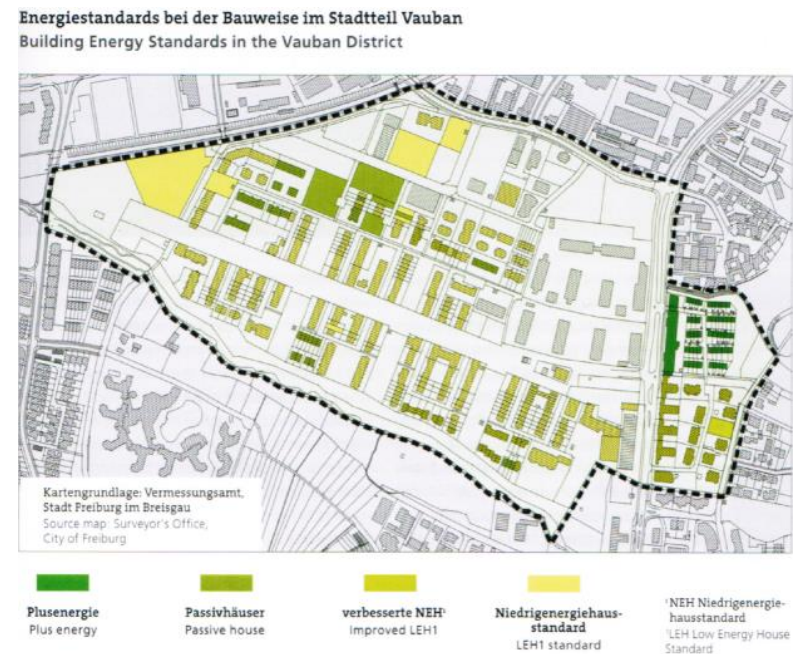

Figure 1: Building Energy standards in the Vauban District;

Source: Surveyor's Office, City of Freiburg, reproduced after Frey, 2011

In the early marketing phase some who planned to invest in such buildings and the Forum Vauban expressed a discontent with the general obligation to connect all buildings to the district heating system, as the applicable heat tariff involves very high fixed costs per connection (once when connecting and annually) and a very low share of marginal costs per $\mathrm{kWh}$ consumed. Despite the extremely low heat demand of passive houses, such a tariff structure only slightly reduces the heating costs compared to standard buildings. As the coordinators of a passive house building group put it: "If we had agreed to connect our building to the district heating network, we would have had to pay an upfront contribution towards network costs that alone is higher than what we pay in total for an own mini-CHP plant." (Building Group Living and Working, 2014)

Forum Vauban voiced this concern and argued that due to the proposed tariff structure the specific heat costs (per $\mathrm{kWh}$ of heat consumed) would rise to unreasonable levels in the case of passive houses.

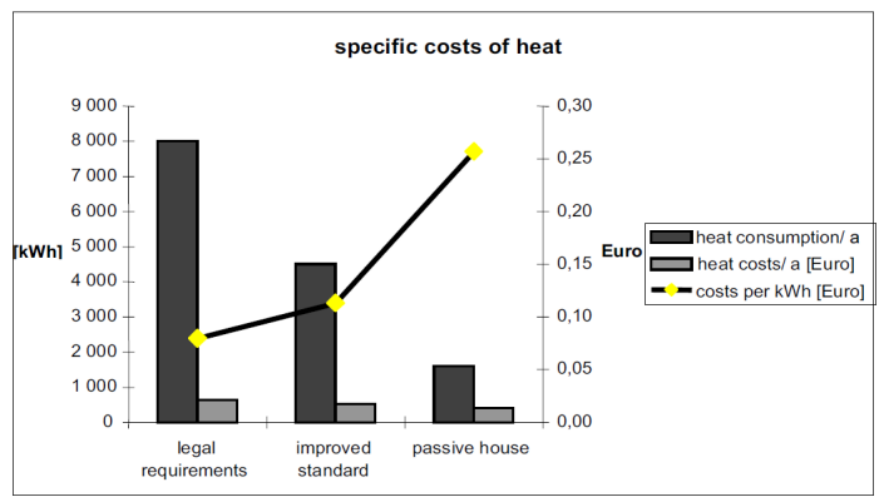

Figure 2: Specific costs of heat from district heating at different levels of consumption; Source: own exemplary calculation, 2004 
The Forum proposed two possible solutions: one would be to waive the obligation to connect to the district heating network for passive houses. This was justified by pointing to the fact that for reaching the passive house standard extra investments had to be made. Against this background it seemed unfair to force the occupants of passive houses to pay very high connection costs on top of these investments, although the low heat demand could be met by alternative stand-alone options in a much cheaper - and still environmentally friendly - way.

As a second alternative, Forum Vauban proposed to significantly 'linearize' the heat tariff. This means that the consumption dependent components (the price per $\mathrm{kWh}$ ) could be made more expensive in order to lower the connection costs. This would keep an incentive in place for a reduction of heat demand (in construction, retrofitting and usage) - at the costs of more energy intensive users of the network.

The utilities operating the heat network argued against both proposals: the tariff was said to reflect the true costs structures and in their view a unified tariff would need to be sustained throughout the city to simplify marketing. To generally waive the obligation to connect passive houses would leave the remaining households with all the costs of the network, and might also impair on the performance of the underutilized infrastructure from an ecological perspective (Freiburg City Council, 1997a).

Since the decision had been taken to invest and expand the heat network into the new district, all current and future users share the interest to keep the total heat demand and the number of connections above certain thresholds and hence allow for reasonably low prices. When a heat network is operated by a municipally owned utility - as in the case of Freiburg its economic performance (annual profits or losses) is highly relevant also for the municipal budget. Consequently, it is regarded to be in the interest of the public to strengthen the economic performance of the infrastructure network rather than weakening it by allowing for exemptions from the connection obligation. In the case of Freiburg's utility FEW, and its regional successor Badenova, the municipal perspective is represented by the Lord Mayor who regularly heads its board of directors.

\subsection{How the conflict was settled}

The environmental department of the municipal administration acknowledged the arguments of both parties to be valid (Freiburg City Council, 1997a). In order to settle the dispute, a compromise in the form of "three exemption clauses" was developed. A decision was taken by the city council (Freiburg City Council, 1997a) to wave the obligation to connect to the DHS in purchase agreements for passive house sites under three conditions: 1) prove with a very demanding and expensive certification documentation that the planned building is truly fulfilling the specified passive house standard; 2) install a device for the harvesting of solar heat (a collector of a certain surface plus a storage facility); and 3) refrain from using a number of options for covering the small remaining heat demand which were considered ecologically inappropriate. Among these forbidden options were all heat pumps except for highly efficient ones and the cheapest option of them all: direct electric heating of hot water and air. 
In the end, only a handful of passive- house builders/ tenants made the effort to prove the fulfilling of all three criteria and instead accepted the comparatively high contribution to the fixed costs of the network in addition to their investments in much improved low-energy buildings.

\subsection{Reconsideration of the district heating strategy?}

As a result of the heated debates in the mid 1990's, the energy policy agenda in Freiburg had to be revised. It had become clear, that the two strategies of expanding the heat network and of lowering the energy consumption of buildings down to passive house levels and below cannot be applied in the very same area, without drastically increasing costs. The longstanding consensus, that an expansion of district heating networks and CHP capacities is the superior way to reach Freiburg's energy policy objectives has now been put into question on economic and ecological grounds, as the specific heat demand in new built or energetically refurbished districts is drastically decreasing. As a spokesperson of the building group 'living and working' states: "Passive houses feature such a low heat demand, that a connection to district heating makes no sense: financially, but also ecologically, due to distribution losses" (Building Group Living and Working, 2014). This was already appreciated in 1997 by the environmental department in a bill proposed to the city council (Freiburg City Council, 1997a). The requested re-evaluation and long-term perspective, however, has not ruled out some later expansions of district heating networks in the city, one of which is servicing e.g. the new sub-district of Westarkaden since 2013.

\section{Discussion}

What can we learn from this instance of two visions for greening the energy supply of private homes which conflicted with each other in a particular locality? Are there lessons to be learned about how such conflicts can be dealt with in a more productive way? And in the first place, how can we understand and interpret the dynamics at play in this particular case and the relevance of such conflicts for our understanding of urban infrastructure change towards sustainability?

First, we see that two strategies came into conflict which both aimed at reducing the negative impacts of conventional heat provision. They had been developed independently from each other in two distinct fields, and they involve different actor groups, institutions and practices; in short they are about two distinct socio-material configurations of sustainable urban futures. The strategy to develop district heating and CHP capacities was a city wide strategy and applied whenever a larger urban development was planned. Passive houses and models of solar architecture have so far been developed by a national and international network of proponents, many of them architects. They were applied in Freiburg so far only at the level of individual housing projects. The intended 'up-scaling' of these models to the scale of a district and the suggested implementation in the new 'model district' now made this strategy incompatible with the established strategy of expanding the heat network into the 
same area. Although the obligation to connect was maintained in the Vauban area and the DHS strategy was further prolonged in later urban developments, the critical questions about the long-term economic feasibility of the DHS strategy in times of decreasing heat demands, which surfaced due to this conflict, can no longer be ignored since then. As the energy expert of the green group in the city council acknowledged in an interview in 2009: "Today, as far as new built districts of passive houses in Freiburg are concerned, the option of district heating is passé, due to the tremendous decrease in heat demand" (Interview 27. March 2009)

Jensen et al., 2013 suggest to call urban places at which such frictions emerge from the interplay of distinct socio-technical systems "urban junctions". In such junctions not only different subsystems but also related sets of practices \& social groups will interplay in new and place specific ways - reflecting the specific frictions that emerged in the various subsystems. In the Vauban development area the DHS-strategy was set to interfere with the upscaled passive house strategy, which threatened to lower the aggregated heat demand under a level that is required for an efficient district heating system (seen from the perspective of the currently dominating engineering model). Through this place related linkage, the friction inherent to the DHS strategy came to the fore. The place of the Vauban district was also relevant in another sense: the privileged locality and the related 'model district ambitions' also included high expectations with regard to citizens' participation in planning. Due to these model district ambitions, the planning process has been conducted in a much more participatory way than usual. Many meetings were held in which city councilors and members of the administration discussed with engaged citizens. The prospective passive house builders and tenants had venues and opportunities to meet, strategize and get attention. The Forum Vauban was developed into a strong voice of the future citizens. Together, all this enabled the articulation and discussion of individual perspectives and finally brought inherent frictions of the various energy political strategies to the light.

In this process, proponents of both strategies employed and had to react to ethical as well as scientific arguments in order to legitimize their strategies: should PH dwellers be obliged to connect and contribute as much as any ordinary household to the fixed costs of the network despite their low consumption which technically opened them a much cheaper alternative: electric heating? Would the alternative consumption of precious electricity for low temperature space heating not disqualify the passive house strategy as something unecological? At least such a further 'electrification' of heat provision would go against the longstanding efforts in Freiburg to reduce the share of nuclear energy. The two camps both felt that they pursued a good cause, and it actually was the same cause: to provide comfortable living space in the most efficient, eco-friendly or even sustainable way. They prioritized different means to this end (centralized versus stand-alone; focus on heat provision vs minimization of heat consumption) which were each tied into different socio-technical configurations and pathways to a sustainable urban future.

The particular discursive setting of the conflict was characterized by two additional aspects of place and identity: the ambition to make the 'model district' a showcase of sustainability; and the perception that the 'solar city' of Freiburg had to continuously pioneer in environmental policies was mobilized in support of the passive house strategy. 
On one hand we see an exceptionally strong capacity to govern such infrastructural decisions in Freiburg: Besides the universal mandate as it is granted to German municipalities in $\S 28,2$ of the constitution, there is also a longstanding tradition to set and pursue ambitious energy policy objectives in Freiburg and, very importantly, the control over the regional utilities has been preserved. As yet, the example of the DHS strategy and how it was defended in Freiburg also indicates that the development of line-bound infrastructures with high investment costs is set to produce severe path dependencies and constrain future decisions on a municipal level as much as on any other governance level.

However, the question remains: Are we actually seeing reflexive and open-ended negotiations of the merits of the alternative strategies in our case? The final outcome of the process has been a marginally modified obligation to connect passive houses to the DHS of the Vauban area. The two competing strategies have both been pursued further: The district heating system has been expanded into newly developed areas of the western suburbs - where no passive houses are built. And the 'passive house standard' continues to play an important role in positioning the city as an energy political frontrunner - though with regard to beacon projects of retrofitting and in areas where an expansion of the district heating system is not feasible anyway. In effect, it seems that the passive house ambitions have been generally subordinated to the economic feasibility of the heat network. These outcomes suggest that the municipal administration and the utility as the most influential actors as well as the majority of the city council have not yet developed the will and found a way to overcome the severe lock-in to the DHS strategy. It may thus well be that this conflict was only settled temporarily and urban politics only managed to postpone a deeper going engagement with this issue. Just like the development of the 'Vauban model district' created a 'junction' between the development of passive houses and district heating, another opportunity to plan for a larger new development may well again create such a 'hot-spot' around which new dynamics and constellations of sustainable urban residential heat supply can emerge and particular notions and visions of sustainability congeal.

\section{In conclusion: Implications for analysis and the designing of governance arrangements}

We wanted to learn from our analysis what kind of aspects and processes deserve our attention in order to better understand the contentious development of local strategies of energy transformation. We furthermore want to reflect on possible implications of such a perspective on how policies and, on a meta-level, how governance arrangements should ideally be shaped. Finally, we will take a very brief outlook on how further research may contribute to this agenda.

\subsection{Conclusions regarding our analytical perspective}

We have shown that energy political ambitions in Freiburg are guided by a broad vision of how to transform energy supply and demand. This vision has been widely shared and remained uncontested over many decades. Even though this is the case, there have been a 
number of conflicts around more specific issues like the question of how to best achieve a more sustainable system of residential space heating. Energy policy decision making - at least in Freiburg - is hence not best understood as a systematic process of visioning with regular cycles of re-orientation, as it would be considered ideal from the perspective of Transition Management. What we rather need to recognize is that any attempt to follow up on a widely shared vision of system transformation, e.g. by supporting particular socio-technical niches, is regularly threatened by potential contestation and de-legitimization.

While a certain level of frictions and contestations around infrastructures and their further development is not unusual, there seem to be particular periods and constellations in which such frictions within established regimes and transformation pathways become more prominent and potentially game-changing. Our example of the planning of a large urban development, loaded with the ambition of becoming an eco-district, is such a case where established socio-technical configurations can become 'hot' and problematic again and open up opportunities for renegotiation and successful contestation. Even very temporary local constellations (like the opportunity for planning a new district) can modulate long-term policies in such a case, like the DHS-strategy or the solar architecture and passive house strategy in Freiburg. Potentially, such constellations mediate the emergence of new understandings of sustainable urban transformations and redistribute socio-material relations and power. The reconfiguration of heat infrastructures through energy efficient buildings even if not completely successful in our example - would be such a case.

The arguments used within such conflicts are worth our attention since they can point to substantial frictions within the entrenched regimes as well as within alternative configurations. Moreover, un-anticipated trade-offs may be discovered in such conflicts. However, while the arguments exchanged in such disputes may be a rich source of information and while the public contestation of transition pathways may provide valuable opportunities for deliberation, the role of rational arguments in such conflicts is often also limited: Authoritative decisions will in the end mostly reflect the interests and somewhat stabilized power balances within the city administration. To the extent that we can assume a well informed and democratic decision making process in the city council - it will also reflect the opinion of a majority in the city council. We discussed an extreme case where Forum Vauban, an organization external to the municipal administration, gained an outstanding recognition for its expertise and also created a high level of legitimacy by representing future inhabitants of the planned district in a process which was deemed to be highly inclusive. However, despite an extraordinary influence on many plans and decisions, this initiative was not able to push through sufficient incentives for energy conservation at passive house level as soon as this came in conflict with the economics of a planned district heating system. Besides the power of argument and persuasion it seems that we also need to appreciate the influence of interests and formal powers as well as institutional and discursive inertia. Nevertheless, the creation of new arenas of development can suddenly provide opportunities for challenging formerly hegemonic positions, particularly in urban contexts where the interplay of various systems of provision often creates ambivalences, trade-offs, and opportunities for the contestation of system boundaries. 
We also feel confirmed in our belief, that much can be gained from studying local and temporary constellations of socio-technical change as a precondition for understanding how socio-technical systems and understandings of sustainability are constantly reconfigured through contentious processes in particular urban contexts. In light of our example, the notions of 'urban junctions' and of 'arenas of development' both seem to be fruitful extensions of our vocabulary. Though such junctions, as our case shows, are often outcomes of emergent and unplanned processes, some lessons may be learnt for policy processes dealing with infrastructure change.

\subsection{Policy implications}

Our starting point here is that new interconnections of different infrastructures, policy fields, social worlds and visions - despite the complexity of such processes - are not merely contingent. Our example may hence also create insights about potential entry points of policy interventions - some of which may actually result from the very fluidity of these emergent constellations. "Embedded urban navigation" like Jensen et al. (2013) call a type of governance which would exploit opportunities that emerge at urban junctions, "entails the generation of new associations and interdependencies across traditional system boundaries [and] the on-going re-contextualization and reconfiguration of urban practices and subsystems." (Jensen et al., 2013: 10)

The very notion of 'urban junctions' could be developed into a heuristic tool which guides the attention of any actor in the (local) 'energy policy game', but most pertinently the attention of local governments to the sites (in a temporal, a socio-spatial and an institutional sense) at which dynamics are likely to unfold that may re-shape the long-term development of particular socio-technical configurations. A general appreciation and valuing of the articulation of potential frictions that aggregate across different systems dynamics, i.e. across sectors or policy fields, may also mitigate the much bemoaned negative effects of policy compartementalization as a characteristic of many urban (and other) governance arrangements.

In terms of how governance processes could be shaped, we are skeptical about the possibility of strategically setting up new 'transition arenas' from scratch (as in Transition Management). Our case has not only shown that energy political stakes can shift rather suddenly due to unexpected opportunities and conflicts. It also fuelled our skepticism against the expectation that intentionally created transition arenas Management would truly help us overcoming existing power imbalances (in line with experiences at a national level e.g. in the case of the Dutch 'Energie Transitie' - Kern and Smith, 2008). What we suggest to explore instead is whether opportunities could systematically be created for the articulation of frictions that occur in any established regime or pathway of transformation. Such institutionalization of openness towards contestation and re-evaluation needs of course to be balanced with the need to come to a sufficiently binding consensus and to consistently pursue strategies over an extended period of time. Too much focus on a continuous re-negotiating of contradictory positions could also result in a stalemate and hence lock-in to an unacceptable 
status quo. To develop a capacity for moderating such processes on the side of local and regional governments is certainly a very demanding challenge, particularly when we consider that any part of the government has its own interests at stake. Researchers analyzing the development of arenas and junctions, bringing their observations into the public debate, could also play a role in this, but certainly need to reflect very critically on their own biases and potential impacts too.

In general, it seems that the long-lasting lock-ins resulting from large investments in network-bound infrastructures with very low marginal costs have been hardly considered in municipal decision making processes. A culture of more continuously allowing potential frictions to come to light and to discuss them in an open and inclusive way could probably save energy users and municipal budgets a lot of money.

\subsection{Research outlook}

By analyzing the frictions between passive houses and district heating development in more depth, we explored some potential mechanisms of contesting and re-negotiating strategies of energy transformation when different visions and constellation start rubbing against each other. Unravelling the driving forces of such emerging conflicts as well as the normative content of the opposing viewpoints would certainly prove helpful also in comparable cases. It would be fruitful for our understanding of infrastructure transitions towards greater sustainability to compare factors that lead to the emergence of such conflicts in a greater number of cases and the resources that actors are tapping into in order to settle these conflicts, even in urban contexts that are less well equipped with both formal powers and expertise. On the basis of further cases, additional insights could be gained for the improvement of metalevel governance strategies.

\section{References}

Badenova, 2014. Ökologie und Nachhaltigkeitsbericht 2013. Badenova, Freiburg.

Brown, R.R., Farrelly, M.A., Loorbach, D.A., 2013. Actors working the institutions in sustainability transitions: The case of Melbourne's stormwater management. Global Environmental Change-Human and Policy Dimensions 23, 701-718.

Building Group Living and Working, 2014. Das Klein-Blockheizkraftwerk; http://www.passivhaus-vauban.de/blockheizkraftwerk.html.

City of Freiburg, 2011. Environmental Policy in Freiburg. City of Freiburg, Freiburg, p. 101.

Coutard, O., Rutherford, J., 2010. Energy transition and city-region planning: understanding the spatial politics of systemic change. Technology Analysis \& Strategic Management 22, 711-727.

Forum Vauban - Mobility WG, 1995. Modellstadtteil Vauban - Verkehrskonzeption: Auf kurzen Wegen und Autofrei ins nächste Jahrtausend! - Stellungnahme des AK Verkehr der erweiterten Bürgerbeteiligung. Forum Vauban, AK Verkehr der erweiterten Bürgerbeteiligung, Freiburg.

Forum Vauban, 1996. Wohnen im Vauban - So kann es werden, wenn Bürger mitplanen. Forum Vauban, Freiburg. 
Frantzeskaki, N., Loorbach, D., 2010. Towards governing infrasystem transitions: Reinforcing lock-in or facilitating change? Technological Forecasting and Social Change 77, 1292-1301.

Fraunhofer IAO, Radecki, A.v., Stryi-Hipp), G., 2013. City Report - Freiburg of Innovationsnetzwerk »MORGENSTADT: CITY INSIGHTS« Fraunhofer IAO, Stuttgart.

Freiburg City Council, 1996a. Proposed resolution / Drucksache G-96/002 Beschlußvorlage: "Energieversorgungskonzept Freiburg 1986: Stand der Umsetzung". Stadt Freiburg Gemeinderat

Freiburg City Council, 1996b. Proposed resolution / Drucksache G 96/033 Beschlußvorlage: "Energiekonzept Vauban". Stadt Freiburg, Freiburg.

Freiburg City Council, 1997a. Proposed resolution / Drucksache G 97150 - Beschlußvorlage: "Bautechnische und städtebauliche Fortentwicklung der Niedrigenergiebauweise in den Baugebieten Rieselfeld und Vauban", Freiburg.

Freiburg City Council, 1997b. Proposed resolution/ Drucksache G 97-097 Beschlussvorlage: "Bebauungsplan Vauban", Freiburg.

Frey, W., 2011. Freiburg Green City - Wege zu einer nachhaltigen Stadtentwicklung Approaches to Sustainable Urban Development. Herder, Freiburg.

Grin, J., Rotmans, J., Schot, J., 2010. Transitions to Sustainable Development - New Directions in the Study of Long Term Transformative Change. Routledge, New York.

Hermann, L., Epp, C., Sperling, C., 1996. Erweiterte Bürgerbeteiligung - Erfahrungen des "Forum Vauban" mit Modellstadtteil in Freiburg im Breisgau. Der Städtetag, 617-621.

Hess, D.J., 2014. Sustainability transitions: A political coalition perspective. Research Policy 43, 278-283.

Hodson, M., Marvin, S., 2010. Can cities shape socio-technical transitions and how would we know if they were? Research Policy 39, 477-485.

Jensen, J.S., Fratini, C.F., Lauridsen, E.H., Hoffmann, B., 2013. Harbour bathing and the urban transition of water in Copenhagen: mediators, junctions and embedded urban navigation, IST 2013, Zurich.

Jorgensen, U., 2012. Mapping and navigating transitions - The multi-level perspective compared with arenas of development. Research Policy 41, 996-1010.

Jorgensen, U., Sorensen, O.H., 1999. Arenas of development - A space populated by actorworlds, artefacts, and surprises. Technology Analysis \& Strategic Management 11, 409-429.

Kern, F., Smith, A., 2008. Restructuring energy systems for sustainability? Energy transition policy in the Netherlands. Energy Policy 36, 4093-4103.

Lange, J., 2009. Unterstützen Sie unser Verkehrskonzept! - Information - Forderungen Unterschriftenliste. AK-Verkehr Vauban, Freiburg.

Lange, J., Heuer, M., Linck, H., Loose, W., Nobis, C., Schieder, A., Sperling, C., Members of the Mobility Working Group, 2003. Umsetzungsbegleitung des Verkehrskonzeptes im Stadtteil Freiburg-Vauban. Forum Vauban, DLR, Ökoinstitut, DBU, Freiburg.

Lauridsen, E.H., Jensen, J.S., 2013. The strictest energy requirements in the world: An analysis of the path dependencies of a self-proclaimed success. Energy Policy 53, 97 104.

Monstadt, J., 2009. Conceptualizing the political ecology of urban infrastructures: insights from technology and urban studies. Environment and Planning A 41, 1924-1942.

Rüskamp, W., 1996. Beworben, gewonnen: Das Freiburger "Forum Vauban" 'wird sein Wohnprojekt auf der UN-Konferenz in Istanbul vorstellen - Großer Auftritt für ein kleines Stadtviertel, Badische Zeitung, Freiburg.

Rutherford, J., 2013. The Vicissitudes of Energy and Climate Policy in Stockholm: Politics, Materiality and Transition. Urban Studies. 
Sperling, C., 1999. Nachhaltige Stadtentwicklung beginnt im Quartier. Ein Praxis- und Ideenhandbuch für Stadtplaner, Baugemeinschaften, Bürgerinitiativen am Beispiel des sozial-ökologischen Modellstadtteils Freiburg-Vauban. Öko-Institut, Freiburg.

Valderrama, A., Jorgensen, U., forthcoming. Creating Copenhagen's Metro - on the role of protected spaces and arenas in transitions ; working draft, unpublished. 